\title{
Then and Now
}

\section{By FRANK BAINES, Saltcoats, Sask.}

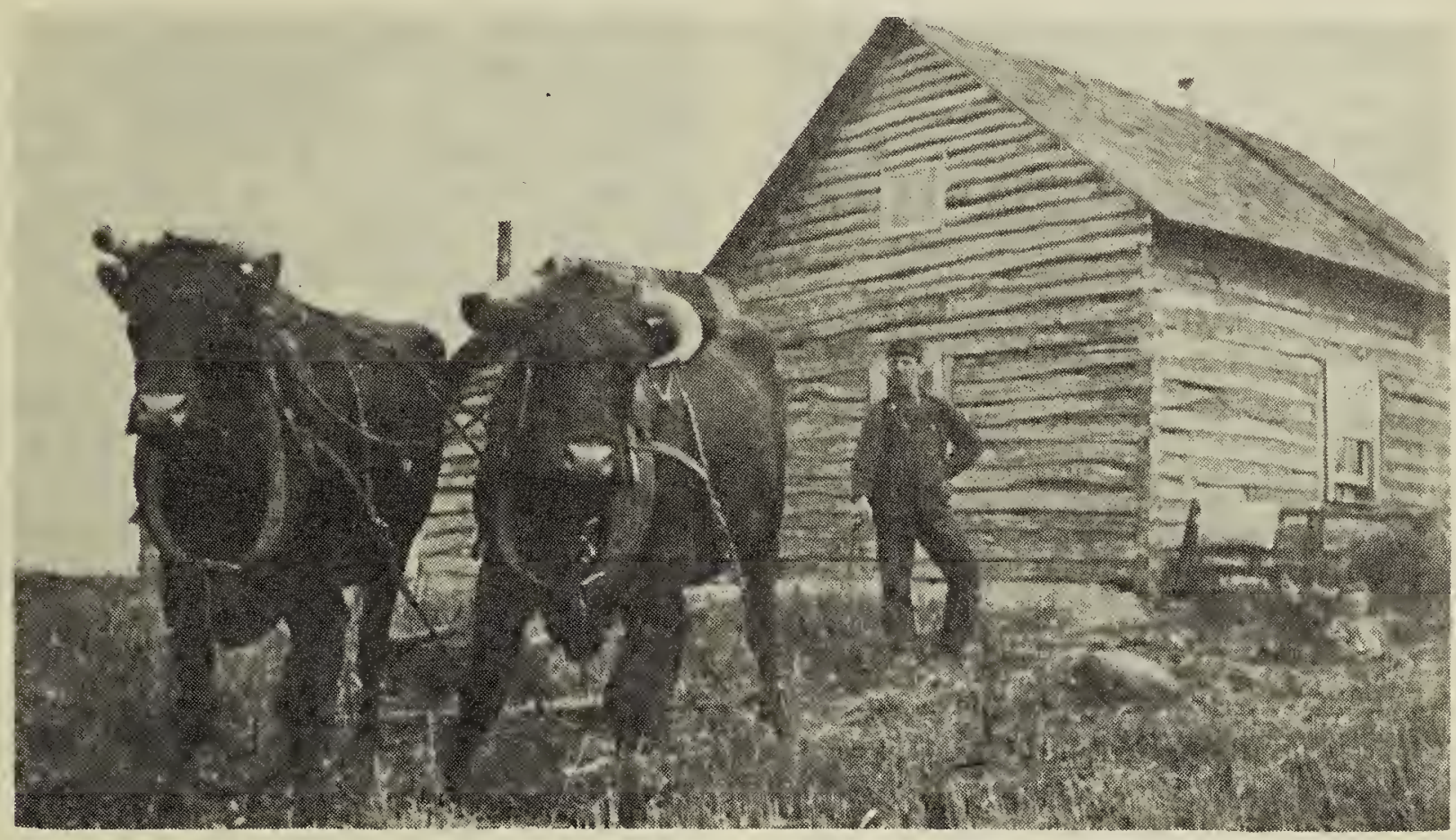

Editor's note: Our Museum of Natural History has been fittingly dedicated to the pioneers of this province. Since the early days of their arrival, many of these have been ardent lovers of nature and of the great open spaces, appreciating, perhaps more than those who came later the necessity for the conservation of our wildlife resources. Typical of these is Mr. Frank Bains, whose early trials and experiences, as recorded here, are strikingly similar to the stories of scores of others, each of whom did his part in laying the foundation of Saskatchewan's parade of progress.

"Then" began in August 1883; "Now" will be the Golden Jubilee Year 1955 - so we will begin with "Then - 1883".

Imagine a family of father, mother, two girls and two boys from the ages of three to eleven years. The parents had been engaged in boot and shoe trade in Manchester, England. In some way they had acquired the desire to go to Canada, where it was said, 160 acres of fertile land could be secured for $\$ 10.00$, with some improvements and residence on the homestead. To an Englishman this seemed almost fabulous.

So it came about that the Baines family took passage on the Steamship Polynesian, and after a rather stormy passage of eleven days, landed at Quebec. From there they took train to Toronto, expecting to meet old friends. In some way they didn't meet the friends, but they did meet a silver-tongued land agent, who soon persuaded them that Crescent City, Assiniboia, North West Territories was the modern Garden of Eden, and all it needed was Adams and Eves and some kids.
In a week they were on the road by way of Detroit, Minneapolis, Emerson and Winnipeg. At that time the C.P.R. - the only beginning of a transcontinental railway _ was not completed along the north of Lake Superior, making the detour into the U.S.A. necessary. In fact the railway was completed only about as far as Moose Jaw that year, but it was being pushed westward as quickly as possible.

At Broadview the newcomers were met by a good driver, a team of horses and a covered wagon. They were told to be ready to start early next morning. This was done and with much excitement the party got on the road north of Broadview. In good time they arrived at the top of the hill and prepared to go down the Indian trail into Qu'Appelle Valley. The wagon wheels were chained together for the steepest parts of the road but the descent was made in safety.

Then came the crossing of the river on the Indian ferry. The team and wagon were driven onto a large scow, the gate closed, and all were drawn across by a long rope at- 
tached to a windlass. Going up the hill things were very much in reverse. Blocks were placed behind the wheels whenever a flattening of the road made it possible to give the horses a rest. So by a series of spurts and rests the ascent to level ground was completed at last. Night was close at hand so camp was made soon after the top was reached.

For the children this was one grand picnic but to the parents it began to look as though homesteading would not be all roses. Supper was prepared and eaten. Beds were made in the wagon for the women and girls - under the wagon for the men and boys. Then to bed.

Just as all were becoming drowsey and the fire was dying down, there came a long drawn wail Whahoo hoo hoo. "What's that?" came from the wagon box. The driver answered by saying, "Oh that's only wolves." "Wolves! Will they eat us?" This in all seriousness from the wagon box. "Oh no, they always eat the men under the wagon first and by the time they've finished your husband they won't want any more." This from the driver who certainly loved his joke, but it was not at all assuring to those who had been brought up in the city on the tales of Little Red Riding Hood and the Big Bad Wolf. However, nothing happened and all too soon the driver called out "Roll Out". Presently we were again on the long, long trail awinding.

Toward night some tents were sighted and one of the newcomers suggested that these must be people from Crescent City out for a picnic. "Oh yes", said the driver, "they're having a picnic alright".

When we drove up beside one of the tents and stopped my father said, "Well, don't stop here, we must get on to the city before dark". "But this is Crescent City and that's your tent. I am unhitching", and he immediately proceeded to do that.

What did he mean? Where is the Crescent? And where oh where is the city? Six tents and one log shanty with a roof. This can't be it! Maybe it's another of his jokes. Some of the occupants of the other tents came and assured us that this was Crescent City. There was no- thing we could do but make the best of it for the night. Perhaps morning would throw a new light on the situation.

But the night was not over yet. Just as we had settled down for the night one of those August thunder showers rolled in from the west. Of course every flash of lightning, and there were many, showed up to advantage through the tent and many of the flashes were accompanied by crashes of thunder that shook the earth on which we were trying to sleep. Rain came down in such torrents that soon a pool formed near the tent door, and someone asked if there was going to be a flood. Wolves last night, water tonight! What next? Bailing out the water that began to get near the beds was next in order. But at last the fireworks began to die down, the thunder rumbled and grumbled off into the distance and finally rest and oblivion reigned over all.

But oh what a beautiful morning! The rain had washed everything clean, even the air smelled as "fresh as a daisy kissed by the dew". The rain drops still hung on the grass and bushes and glistened in the light of the morning sun.

Father took up his muzzle loading shot gun and soon brought home two Sharp-tailed Grouse. That, when fried with bacon, made a breakfast fit for a king - certainly fit for the new settlers.

Of course it turned out that this was Crescent City. "It's all very beautiful but of course we can't possibly stay here. Oh no!" But before you go back you must pay your return fare". "Impossible". So it was the "devil or the deep sea", or rather the prairie - and the devil lost out again.

We will pass over the dangers and difficulties of the first winter but we should mention the patience and kindness of the Indians who lived in the Okanese Indian Reserve near by. Although the settlers overstepped their rights with regard to the Indian Reserve, and although the Indians far outnumbered the settlers, yet no one was molested or injured in any way. In fact $m y$ earliest remembrance of encounters with the Indians was when I was given half a bushel of potatoes in the spring of 
1884. They had been kept in a pit and were in excellent condition. This came, too, at a time when potatoes were not even thought of, with Broadview sixiy miles away and no road for winter. Certainly the Indians set us a good example and this, no doubt, made the settlers at least try to live up to their part. When the so-called Indian Rebellion of 1885 broke out there were no old scores to settle.

Early attempts at farming were very disappointing. Invariably the wheat was frozen before it was ripe. There was no one to give advice, no experimental farms - so things were done on a trial and error basis. Then, too, the land was very fertile, very new, and when properly worked it grew crops lixuriantly, but this made it late in ripening. The varieties of Red and White Fife took longer to mature than thcse used later. More attention was paid to getting the crops in early, after repeated failures. Still grain growing had been so disappointing that many in our locality turned their efforts to stock raising. Cattle, especially, did well on the upland pasture and the peavines in the bushes.

One of the outstanding features of the times was the abundance of so many kinds of game. Buffalo had only just been nearly exterminated but their bones were scattered in such abundance as to give definite cividence of their fcrmer numbers. Yet this had to be before farming could be successful. Black Tail or $\mathrm{Mu}$ 'e Deer were the only kind here at that time. Later they gave place to Virginia or White Tail Deer. But it was the birds that were so much more abundant at that time than now. Ducks, geese, grouse, cranes, plovers, snipes, were here by the thousands, probably by the millions with regard to ducks, geese, cranes and grouse.

Geese and Cranes - Sandhill and Little Brown - made a regular practise of nesting here, but the stately Whooper went further north, though they always stayed here for a time during their spring migration. Today it is a very rare thing for a goose or a crane to nest in this locality. Whooping Cranes are doomed to extinction. Pinneated Grouse are gone. The Passenger Pigeon of Eastern America is exterminated.
The dancing grounds of the Sharptailed grouse are all forsaken and their numbers are so reduced here, that there is probably only one now, where in the early days there would be one hundred.

Actually we are a race of exterminators - killers, so ruthless, so foolish in our killing. Although we have made the Sharp-tailed Grouse our provincial bird emblem, yet we proceed merrily on with a policy that looks as though it will lead to its extermination.

And all the while we tolerate at least two pests that are causing us much annual loss; I refer to the rat and the magpie. I consider them in the same class. Probably the magpie is the worst enemy of all to the Sharp-tail. Certainly they have increased alarmingly lately. They raise as many as fourteen at a brood and they are clever enough to survive. They have even caused much injury to sheep and cattle by pecking at an open sore and preventing it from healing. Why not turn our attention to them for a change.

Probably enough has been said about "Then", although only the surface has been scratched. Now let us glance for a short time to "Now".

In seventy-two years great changes have taken place. From oxen and horses to cars, tractors and aeroplanes, has been a big jump. Our capacity for production per person has probably more than trebled. But so far our means of distribution has not kept pace. No doubt the Hudson Bay route will be developed much more rapidly in the near future.

When our mines begin to operate; when our oil wells come fully into production and our increased productive capacity along agricultural lines finds a better outlet, then we are bound to have an increased population that will create a local demand for much more of our agricultural products, and perhaps our surplus will cease to be a burden.

This is certainly a land flowing with milk and honey, also many other good things. It has a great future if we don't blow the top off with atomic weapons. Why not turn our attention to peaceful pursuits for: "Whatever a man soweth, that shall he reap". There is no escaping that law. 